\title{
The Feminizing Effect of Sexual Violence in Third-Party Perceptions of Male and Female Victims
}

\author{
Eva Mulder $^{1}$ (I) $\cdot$ Antony Pemberton ${ }^{1} \cdot$ Ad J. J. M. Vingerhoets $^{2}$
}

Published online: 27 March 2019

(C) The Author(s) 2019

\begin{abstract}
Various scholars have noted that the label "victim" frequently elicits connotations of stereotypical, passive femininityespecially when the crime entails rape or other forms of sexual violence. In three online experimental studies, British respondents were recruited to test whether written information about a sexual assault led observers to perceive the victim as more feminine in terms of character traits and facial appearance. Study $1(n=139)$ compared observers' perceptions of a male victim to a man accused of sexual assault and a control condition. Study $2(n=165)$ was a conceptual replication, replacing the male with a female target. Study $3(n=278)$ extended Study 1 by adding a condition with a male victim of physical assault and another with a man who had engaged in consensual homosexual sex in order to assess whether feminizing effects were unique to victimization by sexual assault. Results revealed partial support for the feminization hypothesis. Male and female victims were consistently attributed fewer proscriptive masculine traits than target persons in other conditions, as well as more prescriptive feminine traits than target persons in the accused condition. Results for the feminization of facial features were inconsistent. We discuss potential implications of the results for sexual violence awareness-raising campaigns and understanding victims' potential identity struggles.
\end{abstract}

Keywords Sexual violence $\cdot$ Gender $\cdot$ Third party perceptions $\cdot$ Feminization

The term "victim" frequently elicits connotations of stereotypical, passive femininity - especially when the crime entails rape or other forms of sexual violence (Lamb 1999; Mardorossian 2014). Although male-male rape is gradually receiving more academic and societal attention, presentations of male rape are frequently limited to those occurring in a very specific context, such as against gay or prison populations (Cohen 2014; Javaid 2015a). Yet prevalence studies indicate that male sexual assault should not be dismissed as an extraordinary occurrence, or one merely confined to specific population groups. For instance, according to results from the

Electronic supplementary material The online version of this article (https://doi.org/10.1007/s11199-019-01036-w) contains supplementary material, which is available to authorized users.

Eva Mulder

e.mulder@tilburguniversity.edu

1 INTERVICT, Tilburg University, Postbox 90153, 5000, LE Tilburg, the Netherlands

2 Department of Medical and Clinical Psychology, Tilburg University, Tilburg, the Netherlands
National Intimate Partner and Sexual Violence Survey conducted by the Centers for Disease Control and Prevention in 2011 (Breiding 2014), 1.7\% of men in the United States indicate they have been raped (compared to $19.3 \%$ of women), whereas $23.4 \%$ of men indicate they have experienced other forms of sexual assault (compared to $43.9 \%$ of women). Despite these figures (a presumably significant dark number), male victimization often remains depicted as exceptional or negligible.

The association of victimhood and sexual violence with (passive) femininity has been hypothesized to obstruct recognition of male victims of sexual assault and to potentially complicate the reaffirmation of victims' own sense of (masculine) identity (Javaid 2016; Stemple and Meyer 2014). It is not without reason that several anti-rape campaigns have attempted to tackle the persistent myth that "real men can't get raped" (e.g., the anti-rape advertising by SurvivorsUK "Real men get raped" in 2012; SurvivorsUK 2018, and the photography project "Project Unbreakable" set up by Grace Brown in 2011; Brown 2017). This myth is likely to be so tenacious because rape victimization is a doubly feminine phenomenon: (a) because it entails (interpersonal) 
victimization, triggering associations of weakness and vulnerability traditionally associated with femininity and (b) because it forces the victim into a particular role within sexual relations that is typically allocated to the feminine party. Rape hence has been described as a gendering crime, that is, one that has the potential to feminize its victims (Marcus 1992; Mardorossian 2014).

The primary focus of the current paper is whether and how conceptions of gender roles that are subsumed within people's ideas of sexual violence influence their perceptions of (male) victims. At this moment, a small number of experimental studies have investigated the influence of gender stereotypes on perceptions and evaluations of victims (Howard 1984a; Masser et al. 2010). However, very few experimental studies have been conducted that examine whether and how (sexual) victimization changes people's gendered perceptions of a victim (but see, Howard 1984a). The studies presented in the current paper employed experimental designs to investigate whether information about sexual victimization causes observers to feminize the victim. We tested whether respondents ascribe more stereotypically feminine - and fewer stereotypically masculine - traits and facial features to a man (Studies 1 and 3) or woman (Study 2) when they learn that this person was a victim of a sexual assault. To assess whether this potential feminizing effect is specific to victimization through sexual violence, we also examined reactions to the separate components of victimization/interpersonal violence and homosexuality (Study 3).

\section{Gender and Gendering}

To be able to give meaning to the conception of rape as a potentially gendering crime, it is necessary to make a clear (yet simplified: see Ainsworth 2015) distinction between sex and gender. We reserve the term sex for the categories "male" and "female," and we follow previous researchers in broadly defining gender as the cultural significance assigned to the distinction between these categories (Bonthuys 2008; Helgeson 1994; Howard 1984b). The present article focuses on the perceptions of people, and to do so employs a framework wherein particular traits or features are dichotomously categorized as stereotypically feminine or stereotypically masculine (Abele 2003; Abele and Wojciszke 2014; Prentice and Carranza 2002; see Wood and Eagly 2015). Although the individual experience of gender is likely to be much more dynamic, we suggest that the dichotomous approach is a way of stereotyped or heuristic thinking inadvertently endorsed by most people in their perceptions and evaluations of others (see Ridgeway 2009 on framing).

Widely applied measurement instruments such as the Bem Sex Role Inventory (BSRI; Bem 1974) and the Personal Attributes Questionnaire (PAQ; Spence and Helmreich
1978) have traditionally grouped traits perceived as either (stereotypically) masculine or (stereotypically) feminine to measure individuals' (self-)perceptions in terms of gender. Although the BSRI and PAQ may not accurately capture current-day Western men's and women's self-perceptions (Donnelly and Twenge 2017), the adjectives included in the questionnaires remain descriptive of masculine versus feminine gender stereotypes (for a brief overview of validation studies of the BSRI in this regard, see Prentice and Carranza 2002). Thus, stereotypical femininity is associated with vulnerability, emotionality, and passivity (Gilbert 2002) and stereotypical masculinity with notions of toughness, rationality, and action (Connell and Messerschmidt 2005). Broadly speaking, femininity and masculinity dichotomously map onto the domain of warmth, communion, or expressiveness, and onto the domain of competence, agency, or instrumentality, respectively (Abele and Wojciszke 2007).

Despite the persistent presence of gender stereotypes through time, studies have also shown that cultural values and circumstantial factors influence perceptions of gender (Cuddy et al. 2015). For instance, Koenig and Eagly (2014) demonstrated that the observed or expected (occupational) role of a social group influences the character traits people attribute to that group (also Eagly and Steffen 1984). Additionally, studies by Fiske et al. (2002) have shown that whereas housewives as a group are generally rated high in warmth but low in competence in accordance with traditional notions of women, feminists are rated as higher in competence but low in warmth. Hence, associations with particular occupations, studies, roles, etc. may make a person seem more feminine or masculine in the eyes of the perceiver, regardless of their assigned sex. These studies confirm that contextual factors can have a gendering function. Gendering "shows gender as an active ongoing process, rather than something that is ready-made and fixed" (Pilcherm and Whelehan 2004, p. 59; see also Butler 1988). We call a phenomenon gendering when there is something inherent to our understanding of it that (re)produces distinctions between (passive) femininity and (active) masculinity (Mardorossian 2014). In the present article, we seek to provide more substance to the impression that victimization, particularly through sexualized violence, feminizes the victim. This idea has been broadly voiced in feminist scholarship, but has received relatively little consideration in social psychological (experimental) research.

Although the attention paid to the interplay between sexual violence and gendering processes in gender studies has thus far found little resonance in social scientific studies, the presumed function of feminization-normalization of a transgression - fits well within several major theories related to observers' reactions to victims. First, Lerner (1980) coined the just world theory to explain why innocent sufferers are at times met with a (severe) lack of empathy. This author listed a number of coping strategies observers may (unconsciously) 
employ to protect their inherent need to believe that people get what they deserve. Although he framed his theory in terms of justice (also Hafer 2000), it has more recently been posed that people's ideas of deservingness may have more to do with what they normatively expect rather than what they think is ethically correct (Proulx et al. 2012). Following this interpretation of justice, feminization, alongside strategies of blaming the victim, may function to reaffirm one's need to believe in a "normal" world. Second, this interpretation is congruent with system justification theory (Jost and Banaji 1994), which posits that people have a strong need to justify their societal system even when it disadvantages them. Both theories concur that negative observer reactions to victims can be read as an effort to re-establish predictability - be it in the form of justice or the status quo (see also Proulx et al. 2012). In the case of sexual violence, the reaffirmation of normality-hence the diminishment of threat caused by transgression - may well be entangled with the reaffirmation and production of gendered stereotypes (Cohen 2014; Gavey 2005).

\section{Feminization through Sexual Violence}

Various authors have illuminated the gendering dimension of rape. The gendering effect of rape refers to the process of reinforcing and/or scripting gendered stereotypes: masculinizing the perpetrator and feminizing the victim (MacKinnon 1989; Sivakumaran 2005). Marcus (1992, p. 391) keenly summarized the implication of power in the social construction of gender and rape: "masculine power and feminine powerlessness neither simply precede nor cause rape; rather, rape is one of culture's many modes of feminizing women." Although Marcus here emphasized the female victim as subject, the feminizing effects of rape may be all the more apparent when the victim is a man. As stated by Bonthuys (2008, p. 255), "a man who is raped loses his masculine status and becomes, in terms of his sexual role, a woman - while the sexually subordinate status of a woman who is raped is thereby confirmed."

A paper by Mulkey (2004) examining clinical group therapy with men who were victims of sexual violence illustrates the way in which participants experienced a loss of their masculinity and a subsequent need to build a new form of masculine identity. In fact, Mardorossian (2014) suggests approaching femininity and masculinity as structural positions of power, completely dissociated from biological sex. This approach facilitates the acknowledgment that sexual violence concerns constructed vulnerabilities and subordination rather than the female body per se (also Cahill 2000). The gendering effect of sexual violence is perhaps most blatantly illustrated in the context of male prisons, where victims may be forced to wear make-up and dress femininely (Gear and Ngubeni 2002), or in rape as a weapon of war (Bergoffen 2009; Skjelsbaek 2001). However, exclusively focusing on such contexts risks denying or normalizing occurrences of rape that are less "spectacular" and happen closer to home, such as those between intimates or acquaintances (Code 2009).

The sources we mentioned mostly originate from domains in, or intersecting with, gender studies. In social psychological research on perceptions of victims, Howard (1984a) is, to the best of our knowledge, the only researcher who has measured the feminizing effect of rape in an experimental study. Employing a vignette study, Howard found that respondents rated both male and female victims of rape as more feminine than they rated victims of robbery. She furthermore demonstrated that perceptions of femininity were associated with attributions of (characterological) blame. Howard's study focused on the stereotypical "real" (stranger) rape, and hence she suggested that future studies should examine whether similar effects occur in response to acquaintance rape scenarios.

More recently, Papendick and Bohner (2017) demonstrated that even the use of the word "victim" led respondents to perceive a woman who had been raped as weaker, more passive, and more innocent compared to a female "survivor" of rape. Other experimental studies that touch on the gendered aspects of (sexual) victimization include studies that have demonstrated that respondents find feminine-looking victims less blameworthy than masculine-looking victims (Little and Terrance 2010) and victims who express stereotypically feminine emotions (i.e., fear and sadness) more credible than victims who express stereotypically masculine emotions such as anger (Bosma et al. 2018). Additionally, Masser et al. (2010) found that female victims who defy gender stereotypes in addition to victim stereotypes, are judged more negatively than female victims who adhere to a prescriptive feminine role. These studies tap into gendered dimensions of (sexual) victimization, but they have not directly measured whether and how victimization influences third-party perceptions of the (gendered) identity of the target person.

\section{The Current Study}

A likely cause of the lack of experimental research on the gendering effects of rape is the tendency in social psychological experiments to conflate social gender with sex. As noted by Butler (1994, pp. 5-6) regarding the relation of the concepts sex and gender: "that there are competing feminist views on how that tension ought to be formulated is clear, but few, if any, feminist texts proceed with a simple parenthetical conflation of the two." Nevertheless, this is precisely what many social scientists do (most recently, Felson and Palmore 2018). Certainly, the more encompassing definitions of gender are difficult to capture as a factor in a simple experimental design. Yet understanding sex and gender as synonyms prevents researchers from getting a better grasp of the specific effects of gender stereotypes and of processes that can gender 
(for several exceptions, see Little and Terrance 2010; Masser et al. 2010; Wasarhaley et al. 2017).

In the current set of experiments, we aimed to investigate these gendering processes by testing whether sexual victimization, partially in comparison to non-sexual victimization and consensual sex, influences respondents' perceptions of the character traits and facial features of the victim. We were primarily interested in whether (sexual) victimization itself changes third-party perceptions of a target person. This entailed distinguishing between the constructs of gender and sex, whereby gender was operationally defined through stereotypical masculine and feminine character traits, as well as average male and female facial features. Using the BSRI (Bem 1974), Prentice and Carranza (2002) demonstrate a distinction between groups of traits that are perceived as either proscriptive or prescriptive, as well as masculine or feminine. Prescriptive masculine traits, for example, are those traits that are considered generally desirable, but more expected in men than in women. Examples include competence and rationality. Masculine proscriptive traits, on the other hand, are traits that are considered generally undesirable, yet more normatively accepted in men than in women, such as domination or arrogance. We expected that attempts by observers to normalize rape victimization led them to ascribe more feminine traits and less masculine traits to the victim. Additionally, we expected that the feminization of victims also occurred in a more implicit manner, meaning that the process of feminization may occur, at least in part, without full awareness or full control of the observer. To test this point, we included a measure that was intended to indirectly measure whether respondents feminize the appearance of the victim. We hypothesized that feminization is a particular function of sexual victimization, rather than of either (homo)sexuality or interpersonal victimization independently.

In Study 1, the extent of feminization of a male student (including picture) described as (a) a victim of sexual assault was compared with (b) a male student accused of sexual assault or (c) a male student who not described any further. In Study 2, the same conditions were applied but with a female target person. In Study 3, a male target person was depicted once more, and two comparison conditions were added: (d) a victim of physical assault and (e) a male student who engaged in consensual sex with another male student. In all studies, feminization was measured in several ways. First, through prescriptive and proscriptive masculine and feminine traits; second, by an explicit question regarding how feminine or masculine the target person seemed; and third, by an implicit measure that involved selecting one of two morphed pictures. Through morphing the original picture of the target person, masculinized and feminized versions of the original photo were available (DeBruine and Jones 2017). Respondents were asked which of these two versions, in their opinion, most resembled the original picture of the target person. The gender of respondents was included as a predictor in Studies 2 and 3 because previous studies have indicated that men and women respond differently to victims of sexual violence (Grubb and Harrower 2008). Study 3 also included questions about respondents' sexual orientation and experience with (sexual) victimization.

Participants in all studies rated the emotional expression in the picture of the target person. Respondents in Studies 2 and 3 additionally replied to an open-ended question regarding their expectations of what had occurred between the target person and the other student, and Study 3 included a final question about how close or distant respondents felt to the target person. These questions are not directly related to the formulated feminization hypothesis, and their results will be reported separately. Participants in each study were recruited via the online UK-based platform Prolific Academic. For every study, respondents' eligibility criteria included a minimum age of 18 years, UK nationality, and non-participation in relevant previous studies conducted by the authors on the same platform. All studies were reviewed and approved by the relevant ethical review board before data collection. (The complete vignettes are available in the online supplement.)

\section{Study 1}

In Study 1, we tested the hypothesis that male victims of a sexual assault are perceived as more feminine than either persons accused of a sexual assault or control target persons.

\section{Method}

\section{Participants}

Using the calculation software $\mathrm{G}^{*}$ Power (Faul et al. 2007), we determined the required sample size to be able to detect a medium effect among three conditions with a power of .70 at alpha level .05 . This yielded a total required sample size of 129 respondents. Our initial sample size was 151, of which 12 were excluded because they had been allocated to one of the two experimental conditions but failed to answer the manipulation check correctly. The sample that remained consisted of 139 respondents of British nationality (105 women; $M_{\text {age }}=35.8, S D_{\text {age }}=10.5$, range $\left.=18-65\right)$. Participants took approximately $5 \mathrm{~min}$ to complete the survey and were awarded $£ .50$ for their participation.

\section{Procedure and Materials}

Participants were informed that in our study they would be asked to make an estimation of the personality of a target person based on a picture of that person. They were additionally warned that the study might include sexual and/or 
potentially upsetting information. Participants consented to participate in the study by entering their prolific ID number following information about the study and before being able to continue to the experiment. Participants were randomly assigned to one of three conditions. All three conditions (one control; two experimental) included a picture of a young White man. In the control condition, participants were shown the picture without any further descriptions besides his name. In the experimental conditions, participants were additionally informed either that the depicted individual had been accused of or had become a victim of sexual assault during a party at his college.

Participants were asked to take a careful look at the photo and rate the man in the picture on 28 (randomized) traits. Additionally, participants were asked to what extent they thought the man in the picture expressed the following emotions: anger, sadness, disgust, fear, contempt, happiness, guilt, and shame. Afterwards, participants were asked to select one of two pictures (feminized vs. masculinized) that they thought more closely resembled the first picture they had seen. The placement of these pictures on the screen (left - right) was randomized: each featured on the left and the right half of the time. At the end of the questionnaire, respondents were asked to provide demographic information. Finally, respondents were asked what was indicated in the description attached to the picture they saw of Michael (accused of sexual assault; victim of sexual assault; nothing). This question served as a manipulation check.

Vignettes The vignettes included limited information about a student named Michael. In the victim condition:

Michael has become a victim of sexual assault during a fraternity party at his college. He has reported the incident to the University Board. Although the alleged perpetrator claims otherwise, Michael states that the sexual activity between them was not consensual. Michael explains that they had both had a lot to drink. He states that he told the alleged perpetrator "no" several times, but was too confused and scared to physically resist or start shouting.

In both victim and accused conditions, the gender of the other party (accused or victim respectively) remained unspecified. (For all vignettes used in the three studies, see the online supplement.)

Feminization Versus Masculinization The gendering effect of sexual assault was measured through the attribution of personality traits to the target person. A selection of six prescriptive masculine (i.e., decisive, self-reliant, high self-esteem, competent, disciplined, and rational; $\alpha=.83$ ) and six proscriptive masculine traits (i.e., controlling, cynical, self-righteous, arrogant, domineering, and insensitive; $\alpha=.90$ ), as well as six prescriptive feminine (i.e., warm, kind, sensitive to the needs of others, friendly, patient, and helpful; $\alpha=.91$ ) and six proscriptive feminine traits (i.e., child-like, naïve, overly emotional, weak, melodramatic, and gullible; $\alpha=.80$ ), was taken from Prentice and Carranza (2002). Each was rated on a 7-point scale ranging from 1 (not at all) to 7 (very). Responses across each set of six items were averaged so that higher scores indicated stronger endorsement of a trait dimension. Two additional explicit items were included that required respondents to rate how "feminine" and how "masculine" they perceived Michael to be.

Morphed Pictures As an implicit measure of feminization, participants were asked at the end of the survey to select the one of two pictures they thought more closely resembled the first picture they had seen of Michael. In fact, neither of the two pictures was the original picture to which participants had been exposed. Rather both pictures were 50\% morphed versions that rendered the face either more masculine or more feminine. All pictures were taken from an open access image base (DeBruine and Jones 2017; credited to faceresearch.org; see the online supplement), and were tested in a pilot study $(n=69)$ on several features, including perceived age, attractiveness, and general impression. All but one of these respondents could identify which picture had been feminized.

\section{Results}

\section{Character Traits}

A one-way Multivariate Analysis of Covariance (MANCOVA) was conducted that included the dependent variables: prescriptive masculine traits, prescriptive feminine traits, proscriptive masculine traits, proscriptive feminine traits, and the two one-item ratings of how explicitly masculine and feminine the target person seemed. Because there was a vastly uneven distribution of male $(n=33)$ and female $(n=$ 105) respondents, respondent gender was included as a control variable, but not as an independent variable in the MANCOVA. Cell sizes ranged from 42 to 51 participants. We used Dunnett's (1985) tests with victim condition as the reference group to probe significant effects. Correlations and descriptive statistics are presented in Table 1, and group comparisons are displayed in Figs. 1 and 2.

There was a statistically significant overall multivariate main effect across the dependent variables for the experimental condition, $F(12,260)=1.81, p=.046$, Wilks' $\Lambda=.85$, $\eta_{\mathrm{p}}{ }^{2}=.08$, but not for gender of respondents, $F(6,130)=$ $2.02, p=.068$, Wilks' $\Lambda=.92, \eta_{\mathrm{p}}{ }^{2}=.09$. Looking at the univariate effects, a significant main effect was found across experimental conditions on proscriptive masculine traits, $F(2$, $135)=4.01, p=.020, \eta_{\mathrm{p}}{ }^{2}=.06$, such that the male target in 
Table 1 Descriptive statistics and correlations of the feminization outcome variables, study 1

\begin{tabular}{|c|c|c|c|c|c|c|c|c|c|}
\hline \multirow[b]{2}{*}{ Variables } & \multirow{2}{*}{$\begin{array}{l}\text { Control } \\
M(S D)\end{array}$} & \multirow{2}{*}{$\begin{array}{l}\text { Victim } \\
M(S D)\end{array}$} & \multirow{2}{*}{$\begin{array}{l}\text { Accused } \\
M(S D)\end{array}$} & \multicolumn{6}{|c|}{ Correlations } \\
\hline & & & & 1 & 2 & 3 & 4 & 5 & 6 \\
\hline 1. Prescriptive masculinity & $4.30(.94)_{\mathrm{a}}$ & $4.30(.79)_{\mathrm{a}}$ & $4.13(.88)_{\mathrm{a}}$ & - & & & & & \\
\hline 2. Proscriptive masculinity & $3.97(1.21)_{\mathrm{a}}$ & $3.46(.92)_{\mathrm{b}}$ & $4.06(.99)_{\mathrm{a}}$ & $.24 * *$ & - & & & & \\
\hline 3. Prescriptive femininity & $3.75(1.14)_{\mathrm{a}}$ & $4.21(.81)_{\mathrm{b}}$ & $3.61(.89)_{\mathrm{a}}$ & $.50 * *$ & $-.38 * *$ & - & & & \\
\hline 4. Proscriptive femininity & $3.09(1.04)_{\mathrm{a}}$ & $3.30(.90)_{\mathrm{a}}$ & $3.06(.82)_{\mathrm{a}}$ & .01 & $.24 * *$ & $.23 * *$ & - & & \\
\hline 5. Explicit femininity & $2.22(1.21)_{\mathrm{a}}$ & $2.74(1.27)_{\mathrm{b}}$ & $2.12(.92)_{\mathrm{a}}$ & .07 & -.07 & $.34 * *$ & $.52 * *$ & - & \\
\hline 6. Explicit masculinity & $5.10(1.15)_{\mathrm{a}}$ & $4.57(1.21)_{\mathrm{a}}$ & $4.64(1.48)_{\mathrm{a}}$ & $.40 * *$ & $.22 *$ & .06 & -.09 & $-.28 * *$ & - \\
\hline 7. Implicit femininity & $1.37(.49)_{\mathrm{a}}$ & $1.65(.48)_{\mathrm{b}}$ & $1.45(.50)_{\mathrm{a}, \mathrm{b}}$ & .08 & -.02 & .05 & -.00 & .11 & -.06 \\
\hline
\end{tabular}

$n=139$. Means with different subscripts in a row differed significantly $(p<.05)$

$* p<.05 . * * p<.01$

the victim condition was regarded as less proscriptively masculine than both the control ( $p=.034,95 \%$ CI $[-.92,-.09])$ and accused $(p=.016,95 \% \mathrm{CI}[-1.00,-.12])$ men. The main effect for prescriptive feminine traits was also significant, $F(2$, $135)=4.65, p=.011, \eta_{\mathrm{p}}{ }^{2}=.06$, such that the victimized man was rated as significantly more prescriptively feminine than both the control $(p=.038,95 \%$ CI $[.07, .85])$ and accused $(p=.008,95 \%$ CI $[.19,1.01])$ men. Furthermore, a significant effect of type of description was found on the explicit femininity rating, $F(2,135)=3.86, p=.023, \eta_{\mathrm{p}}^{2}=.05$, wherein the male victim was perceived to be more explicitly feminine than both the control $(p=.050,95 \%$ CI $[.06, .99])$ and accused $(p=.024$, CI $[.14,1.12])$ men. Thus our hypothesis was supported in that the victimized man was perceived, by both women and men, as less proscriptively masculine, more prescriptively feminine, and more explicitly feminine than the control or accused men.

No significant main effects were found on the dimensions of prescriptive masculine traits, $F(2,135)=.60, p=.550$, $\eta_{\mathrm{p}}{ }^{2}=.01$, and proscriptive feminine traits, $F(2,135)=1.16$, $p=.316, \eta_{\mathrm{p}}{ }^{2}=.02$. Also, no significant effect was found for explicit masculinity ratings of the target person, $F(2,135)=$ $2.52, p=.084, \eta_{\mathrm{p}}{ }^{2}=.04$. Thus support for our hypotheses did not extend to perceptions of prescriptive masculinity, proscriptive femininity, or explicit ratings of masculinity.

Re-running the three significant analyses with the accused condition as reference group demonstrated there were no significant differences between the accused and the control condition (proscriptive masculinity: $p=.886$; prescriptive femininity: $p=.712$; and explicit femininity: $p=.886$ ). Although not related to our hypotheses, it is interesting that the accused male perpetrator was regarded no differently from the neutral control target across all six of our measures of masculinity and femininity.

\section{Manipulated Pictures}

The Chi-square test of homogeneity indicated that the proportion of selected feminized pictures was not equal across conditions, $\chi^{2}(2)=7.89, p=.019, \phi_{\mathrm{C}}=.24$. Respondents more frequently selected the feminized picture in the victim condition compared to the control condition, $\chi^{2}(1)=6.49, p=.011$, $\phi_{\mathrm{C}}=.28$. In the control condition, $37.3 \%(n=19)$ of respondents chose the feminized picture as the one more closely resembling the original picture, whereas in the victim condition, $65.2 \%(n=30)$ of respondents chose the feminized

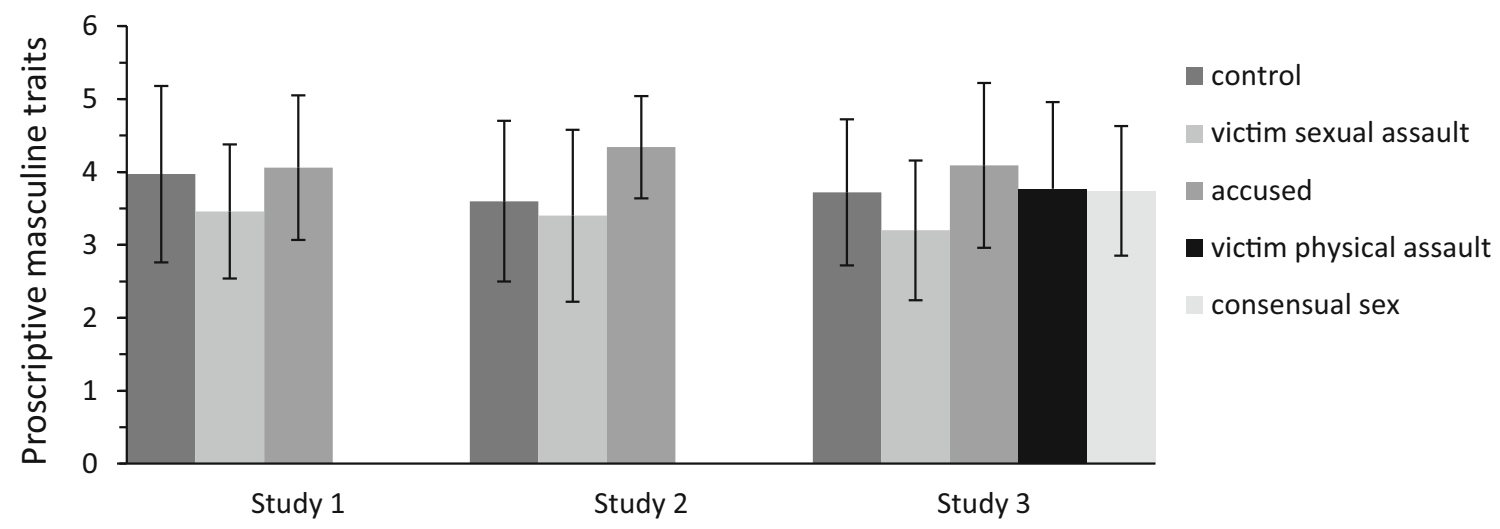

Fig. 1 Attribution of proscriptive masculine traits in experimental conditions in studies $1-3$. Error bars denote $\pm 1 S D$ around the mean 


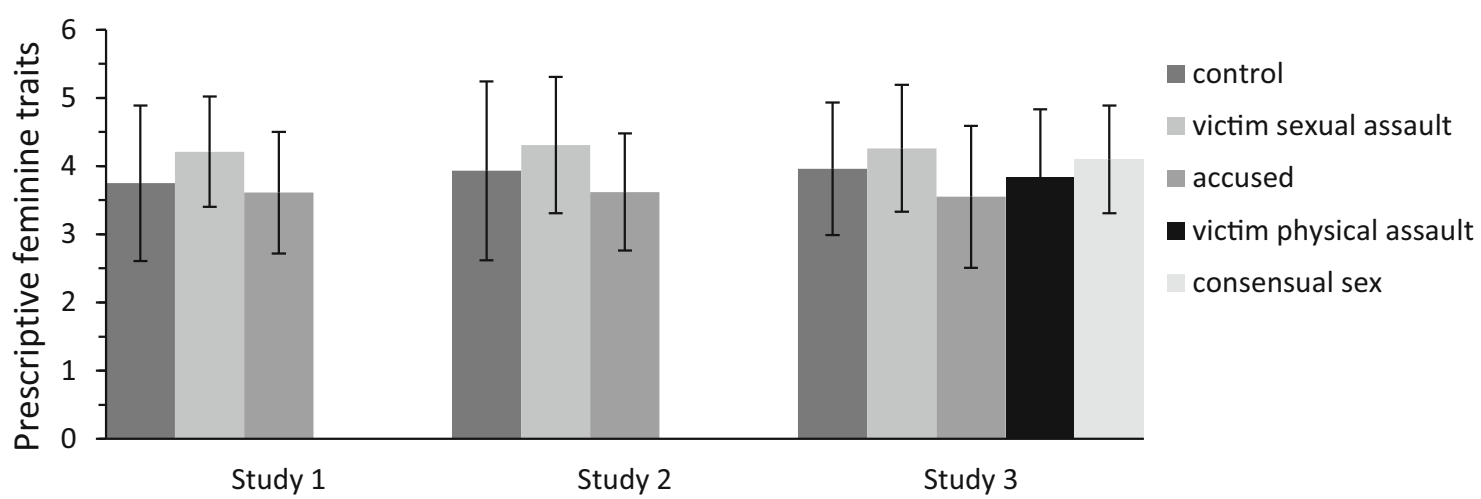

Fig. 2 Attribution of prescriptive feminine traits in experimental conditions in studies $1-3$. Error bars denote $\pm 1 S D$ around the mean

picture. The comparison between the victim condition and the accused conditioned $(45.2 \%, n=19)$ followed a similar pattern but was not significant $(p=.095)$.

\section{Study 2}

In the first study, extensive support was found for the hypothesis of victim feminization. Male victims were perceived as more feminine than target persons in other conditions on two of the four character trait dimensions. Their facial appearance was also reevaluated as more feminine compared to the control condition. A second study was conducted to assess whether similar feminization patterns could be found in response to female target persons. We suspected that processes of feminization would be more difficult to detect because respondents are likely to rate women as feminine regardless of victim status.

\section{Method}

\section{Participants}

Participants were recruited in the same way as in Study 1 by using the same selection criteria. Using $G^{*}$ Power, we determined our sample size to detect a small-to-medium effect $\left(\mathrm{f}^{2}=.05\right)$ between three conditions with a power of .70 at alpha level .05 . This yielded a total required sample size of 159 respondents. The collected respondent sample consisted of 183 respondents, of which 18 people were excluded because they had been allocated to one of the two experimental conditions but failed the manipulation check. The sample that remained consisted of 165 respondents of British nationality (86 women; $M_{\text {age }}=36.2, S D=12.6$, range $=18-80$ ). Participants needed approximately 5 to 6 min to complete the survey and received $£ .70$ for their participation.

\section{Procedure and Materials}

Study 2 was almost an exact duplication of Study 1, except that the current study used a picture of a White female target person named Melanie instead of a male target person. Additionally, one open question was added after the manipulation check in the two experimental conditions. Respondents were asked to describe what they imagined had happened during the sexual assault of which the target person was the accused or the (alleged) victim. Personality traits were again grouped under proscriptive masculine traits (Cronbach's alpha in the present study $=.86$ ), prescriptive masculine traits ( $\alpha=.78)$, proscriptive feminine traits $(\alpha=.79)$, or prescriptive feminine traits $(\alpha=.93)$.

\section{Results}

\section{Character Traits}

A two-way Multivariate Analysis of Variance (MANOVA) was conducted that included the dependent variables: prescriptive masculine traits, prescriptive feminine traits, proscriptive masculine traits, proscriptive feminine traits, and the two explicit one-item ratings femininity and masculinity. Type of description (condition) and respondent gender were included as independent variables, resulting in a $3 \times 2$ between-subjects design, with cell sizes ranging from 18 to 31. Dunnett's (1985) tests with victim condition as the reference group were used to probe significant effects. Correlations and descriptive statistics are presented in Table 2, and group comparisons are displayed in Figs. 1 and 2.

There was a statistically significant overall multivariate effect across the dependent variables for the experimental condition, $F(12,306)=2.36, p=.006$, Wilks' $\Lambda=.84, \eta_{\mathrm{p}}{ }^{2}=.09$, and for respondent gender, $F(6,153)=2.24, p=.043$, Wilks' $\Lambda=.92, \eta_{\mathrm{p}}{ }^{2}=.08$. The interaction effect between respondent gender and experimental condition was not statistically significant, $F(12,306)=.66, p=.786$, Wilks' $\Lambda=.95, \eta_{\mathrm{p}}{ }^{2}=.03$. 
Table 2 Descriptive statistics and correlations of the feminization outcome variables, study 2

\begin{tabular}{|c|c|c|c|c|c|c|c|c|c|}
\hline \multirow[b]{2}{*}{ Variables } & \multirow{2}{*}{$\begin{array}{l}\text { Control } \\
M(S D)\end{array}$} & \multirow{2}{*}{$\begin{array}{l}\text { Victim } \\
M(S D)\end{array}$} & \multirow{2}{*}{$\begin{array}{l}\text { Accused } \\
M(S D)\end{array}$} & \multicolumn{6}{|c|}{ Correlations } \\
\hline & & & & 1 & 2 & 3 & 4 & 5 & 6 \\
\hline 1. Prescriptive masculinity & $4.62(.96)_{\mathrm{a}}$ & $4.53(.82)_{\mathrm{a}}$ & $4.28(.62)_{\mathrm{a}}$ & - & & & & & \\
\hline 2. Proscriptive masculinity & $3.86(1.10)_{\mathrm{a}}$ & $3.40(1.18)_{\mathrm{b}}$ & $4.34(.70)_{\mathrm{c}}$ & .04 & - & & & & \\
\hline 3. Prescriptive femininity & $3.93(1.31)_{\mathrm{a}, \mathrm{b}}$ & $4.31(1.00)_{\mathrm{a}}$ & $3.62(.86)_{\mathrm{b}}$ & $.44 * *$ & $-.54 * *$ & - & & & \\
\hline 4. Proscriptive femininity & $3.04(1.03)_{\mathrm{a}}$ & $2.99(.73)_{\mathrm{a}}$ & $3.40(.85)_{\mathrm{a}}$ & $-.23 * *$ & $.27 * *$ & .08 & - & & \\
\hline 5. Explicit femininity & $4.45(1.43)_{\mathrm{a}}$ & $4.71(1.43)_{\mathrm{a}}$ & $4.20(1.20)_{\mathrm{a}}$ & $.18 *$ & $-.53 * *$ & $.60 * *$ & .00 & - & \\
\hline 6. Explicit masculinity & $3.30(1.56)_{\mathrm{a}}$ & $2.92(1.38)_{\mathrm{a}}$ & $3.46(1.33)_{\mathrm{a}}$ & -.06 & $.52 * *$ & $-49 * *$ & .015 & $-.68 * *$ & - \\
\hline 7. Implicit femininity & $1.52(.50)_{\mathrm{a}}$ & $1.58(.50)_{\mathrm{a}}$ & $1.50(.50)_{\mathrm{a}}$ & .05 & $-.18 *$ & $.19^{*}$ & -.08 & $.17 *$ & -.13 \\
\hline
\end{tabular}

$n=165$. Means with different subscripts in a row differed significantly $(p<.05)$

$* p<.05 . * * p<.01$

Experimental Conditions Looking at the univariate effects across experimental conditions, a significant main effect was found on proscriptive masculine traits, $F(2,158)=9.87$, $p<.001, \eta_{\mathrm{p}}{ }^{2}=.11$, such that the female target in the victim condition was regarded as less proscriptively masculine than both the control $(p=.038,95 \%$ CI $[-.88,-.02])$ and the accused $(p<.001,95 \%$ CI $[-1.37,-.50])$ women. The main effect for prescriptive feminine traits was also significant, $F(2,158)=4.53, p=.012, \eta_{\mathrm{p}}{ }^{2}=.05$, such that the victimized woman was rated as significantly more prescriptively feminine than the accused woman ( $p=.003,95 \%$ CI $[.22,1.16])$, although not significantly more than the female target in the control condition $(p=.12)$. Thus our hypothesis was partly supported in that male and female respondents perceived the victimized woman as less proscriptively masculine than both the control and accused women, as well as more prescriptively feminine compared to the female target in the accused condition.

No significant main effects were found on the dimensions of prescriptive masculine traits, $F(2,158)=2.81, p=.063$, $\eta_{\mathrm{p}}{ }^{2}=.03$, and proscriptive feminine traits, $F(2,158)=3.03$, $p=.051, \eta_{\mathrm{p}}{ }^{2}=.04$. Also, no significant main effects were found for ratings of explicit femininity, $F(2,158)=1.91$, $p=.151, \eta_{\mathrm{p}}{ }^{2}=.02$, and ratings of explicit masculinity, $F(2$, $158)=1.60, p=.205, \eta_{\mathrm{p}}{ }^{2}=.02$. Thus support for our hypotheses did not extend to perceptions of prescriptive masculinity, proscriptive femininity, or explicit ratings of femininity or masculinity.

Re-running the analysis with the accused condition as reference group demonstrated that a woman accused of sexual assault was also attributed more proscriptive masculine traits than the control condition $(p=.019,95 \%$ CI $[.07, .90])$. No differences between the accused condition and control condition were found on the dimension of prescriptive femininity $(p=.226)$. Results hence indicate that a woman accused of sexual assault is viewed as more proscriptively masculine than the other female targets.
Gender Differences Looking at the univariate effects for gender of the respondent, a significant effect was found on proscriptive feminine traits, $F(1,158)=4.87, p=.029, \eta_{\mathrm{p}}{ }^{2}=.03$, wherein male respondents generally attributed more proscriptive feminine traits $(M=3.32, S D=.87)$ to target persons than female respondents did $(M=2.99, S D=.91$, Cohen's $d=.37)$. No significant main effects were found on the dimensions of proscriptive masculine traits $(p=.055)$, prescriptive masculine traits $(p=.275)$, prescriptive feminine traits $(p=.978)$, or explicit femininity $(p=.242)$ and masculinity $(p=.647)$. Male respondents thus perceived female targets as more proscriptively feminine than female respondents did.

\section{Manipulated Pictures}

The Chi-square test of homogeneity indicated that respondents did not feminize the facial features of a victim compared to persons in the accused or control condition. The feminized picture was selected $51.7 \%(n=31)$ in the control condition, $50.0 \%(n=28)$ in the accused condition, and $59.2 \%(n=29)$ in the victim condition $(p=.609)$.

\section{Study 3}

In Studies 1 and 2, similar patterns of feminization were found between the victim with the control and accused condition on the trait dimensions of proscriptive masculinity and prescriptive femininity, although absolute feminization (i.e., significant differences between the victim and control condition) was more prominent in the study with male targets. The third study examined reactions toward a male target person (Michael) once more with the aim of investigating whether the feminization effects we had found were unique to sexual victimization. The purpose of this third study was thus to disentangle two components of sexual violence that potentially have a feminizing effect: becoming a victim of (an 
interpersonal) crime and being involved in a homosexual act. Hence, the current study included the three conditions of the previous studies, as well as a condition where Michael states he has become a victim of physical assault and a condition in which Michael reportedly engaged in a one-night stand with another male student.

\section{Method}

\section{Participants}

Participants were recruited in the same way as in Studies 1 and 2 by using the same selection criteria. Using $G^{*}$ Power, the required sample size was calculated for detection of a small to medium effect $\left(f^{2}=.05\right)$ between five conditions with a power of .70 at alpha level .0021 (.05 divided by 24 total planned comparisons with the victim of sexual assault condition). This yielded a total required sample size of 262 respondents. The respondent sample initially consisted of 319 respondents, of which 28 people were excluded because of missing data and another 13 were excluded because they had been allocated to one of the four experimental conditions but failed the manipulation check. The sample that remained consisted of 278 respondents of British nationality (137 women; $M_{\text {age }}=36.6, S D=12.2$, range $=18-72$ ). Of these respondents, 18 identified as gay, lesbian, or bisexual; 255 as heterosexual; and five preferred not to answer; $28.1 \%(n=78)$ of the total sample confirmed that they or someone close to them had been a victim of (sexual or physical) violence. Participants needed approximately 8 to $10 \mathrm{~min}$ to complete the survey and received $£ 1.00$ for their participation.

\section{Procedure and Materials}

Study 3 was similar in design to Studies 1 and 2. This time, five conditions with a male protagonist were included: a control condition where hardly any information was given and four conditions where the protagonist Michael was described as either accused of sexual assault, a victim of sexual assault, a victim of physical assault, or having had a one-night stand with another man. In contrast to the previous studies, every experimental condition emphasized that the other party featured in the scenario was also a male student. In addition to the feminization-related questions, respondents were asked to describe what they imagined had happened during the sexual/ physical assault of which the target person was the accused or the (alleged) victim. Two questions were included to collect data on sexual orientation and experiences of victimization. Personality traits were again grouped under proscriptive masculine traits (Cronbach's alpha in the present study $=.88$ ), prescriptive masculine traits $(\alpha=.77)$, proscriptive feminine traits $(\alpha=.86)$, or prescriptive feminine traits $(\alpha=.91)$.

\section{Results}

\section{Character Traits}

A two-way Multivariate Analysis of Variance (MANOVA) was conducted that included the dependent variables: prescriptive masculine traits, prescriptive feminine traits, proscriptive masculine traits, proscriptive feminine traits, and two one-item measures of explicit femininity and masculinity. Type of description (experimental condition) and respondent gender were included as independent variables, resulting in a $5 \times 2$ between-subjects design, with cell sizes ranging from 20 to 36 . Neither victim experience nor sexual orientation had an independent effect, so no covariates were included in the final analysis. We again used Dunnett's (1985) tests with victim condition as the reference group to probe significant effects. Correlations and descriptive statistics are presented in Table 3 , and group comparisons are displayed in Figs. 1 and 2.

There was a statistically significant overall multivariate effect across the dependent variables for both the experimental condition, $F(24,915)=1.82, p=.010$, Wilks' $\Lambda=.85$, $\eta_{\mathrm{p}}{ }^{2}=.04$, and gender of respondents, $F(6,262)=3.68$, $p=.002$, Wilks' $\Lambda=.92, \eta_{\mathrm{p}}{ }^{2}=.08$. The interaction effect between respondent gender and experimental condition was not statistically significant, $F(24,915)=1.17, p=.258$, Wilks' $\Lambda=.90, \eta_{\mathrm{p}}^{2}=.03$.

Experimental Condition Looking at the univariate effects, a significant main effect was found for the experimental condition on proscriptive masculine traits, $F(4,267)=4.98$, $p=.001, \eta_{\mathrm{p}}{ }^{2}=.07$. Results showed that the male victim of sexual assault was regarded as less proscriptively masculine than the male victim of physical assault $(p=.014,95 \% \mathrm{CI}$ $[-1.05,-.09])$ as well as the male targets in the consensual sex $(p=.021,95 \%$ CI $[-1.04,-.06])$, the control $(p=.035$, $95 \%$ CI $[-1.02,-.03])$ and the accused $(p<.001,95 \%$ CI $[-1.38,-.40])$ conditions. The main effect for prescriptive feminine traits was also significant, $F(4,267)=3.76$, $p=.005, \eta_{\mathrm{p}}{ }^{2}=.05$, indicating that respondents rated victims of sexual assault as more prescriptively feminine than they did accused persons ( $p=.001,95 \%$ CI $[.26,1.16])$. No significant differences on the dimension of prescriptive femininity were found between perceptions of victims of sexual assault and victims of physical assault ( $p=.073$ ), men engaged in consensual sex $(p=.778)$, and the control condition $(p=.289)$. Furthermore, a significant effect of type of description was found on proscriptive feminine traits, $F(4,267)=2.45$, $p=.046, \eta_{\mathrm{p}}{ }^{2}=.04$. However, no significant differences were found between the victim condition and other groups (accused: $p=.760$; victim physical assault: $p=.854$; consensual sex: $p=.180$; control: $p=.780$ ). Hence, partial support for the hypothesis was found in that male victims of sexual assault were perceived as less proscriptively masculine than male 
Table 3 Descriptive statistics and correlations of the feminization outcome variables, study 3

\begin{tabular}{|c|c|c|c|c|c|c|c|c|c|c|c|}
\hline \multirow[b]{2}{*}{ Variables } & \multirow{2}{*}{$\begin{array}{l}\text { Control } \\
M(S D)\end{array}$} & \multirow{2}{*}{$\begin{array}{l}\text { Victim } \\
\text { sexual } \\
\text { assault } \\
M(S D)\end{array}$} & \multirow{2}{*}{$\begin{array}{l}\text { Accused } \\
M(S D)\end{array}$} & \multirow{2}{*}{$\begin{array}{l}\text { Victim } \\
\text { physical } \\
\text { assault } \\
M(S D)\end{array}$} & \multirow{2}{*}{$\begin{array}{l}\text { Consensual } \\
\text { sex } \\
M(S D)\end{array}$} & \multicolumn{6}{|c|}{ Correlations } \\
\hline & & & & & & 1 & 2 & 3 & 4 & 5 & 6 \\
\hline 1. Prescriptive masculinity & $4.30(.78)_{\mathrm{a}}$ & $4.29(.83)_{\mathrm{a}}$ & $4.29(.81)_{\mathrm{a}}$ & $4.21(.83)_{\mathrm{a}}$ & $4.18(.63)_{\mathrm{a}}$ & - & & & & & \\
\hline 2. Proscriptive masculinity & $3.72(1.00)_{\mathrm{a}}$ & $3.20(.96)_{\mathrm{b}}$ & $4.09(1.13)_{\mathrm{a}}$ & $3.77(1.19)_{\mathrm{a}}$ & $3.74(.89)_{\mathrm{a}}$ & .03 & - & & & & \\
\hline 3. Prescriptive femininity & $3.96(.97)_{\mathrm{a}, \mathrm{b}}$ & $4.26(.93)_{\mathrm{a}}$ & $3.55(1.04)_{\mathrm{b}}$ & $3.84(.99)_{\mathrm{a}, \mathrm{b}}$ & $4.10(.79)_{\mathrm{a}}$ & $.36^{* *}$ & $-.57 * *$ & - & & & \\
\hline 4. Proscriptive femininity & $3.03(1.06)_{\mathrm{a}, \mathrm{b}}$ & $3.20(1.12)_{\mathrm{a}, \mathrm{b}}$ & $3.02(.87)_{\mathrm{a}}$ & $3.34(1.15)_{\mathrm{a}, \mathrm{b}}$ & $3.54(.80)_{\mathrm{b}}$ & $-.41 * *$ & $.24 * *$ & .03 & - & & \\
\hline 5. Explicit femininity & $2.21(.93)_{\mathrm{a}}$ & $2.44(1.15)_{\mathrm{a}}$ & $2.38(1.03)_{\mathrm{a}}$ & $2.63(1.46)_{\mathrm{a}}$ & $2.69(1.20)_{\mathrm{a}}$ & $-.43 * *$ & -.01 & -.03 & $.55^{* *}$ & - & \\
\hline 6. Explicit masculinity & $5.11(1.33)_{\mathrm{a}}$ & $4.65(1.10)_{\mathrm{a}}$ & $4.67(1.23)_{\mathrm{a}}$ & $4.71(1.29)_{\mathrm{a}}$ & $4.74(1.18)_{\mathrm{a}}$ & $.45^{* *}$ & .06 & .09 & $-.42 * *$ & $-.57 * *$ & - \\
\hline 7. Implicit femininity & $1.28(.45)_{\mathrm{a}}$ & $1.31(.47)_{\mathrm{a}}$ & $1.51(.51)_{\mathrm{a}}$ & $1.51(.50)_{\mathrm{a}}$ & $1.40(.49)_{\mathrm{a}}$ & $-.16 * *$ & $-.13^{*}$ & .01 & .12 & $.24 * *$ & $-.26^{*}$ \\
\hline
\end{tabular}

$n=278$. Means with different subscripts in a row differed significantly $(p<.05)$

$* p<.05 . * * p<.01$

targets in all other conditions, as well as more prescriptively feminine than accused men.

No significant main effects were found for prescriptive masculinity $(p=.948)$, explicit femininity $(p=.392)$, or explicit masculinity $(p=.480)$. Thus, support for our hypotheses did not extend to perceptions of prescriptive masculinity, proscriptive femininity, or explicit ratings of femininity and masculinity.

Re-running the three significant analyses with the accused condition as reference group demonstrated that the male target in this condition was also perceived as less prescriptively feminine $(p=.009,95 \%$ CI $[-.98,-.11])$ and less proscriptively feminine $(p=.045,95 \%$ CI $[.07, .96])$ than a man who had engaged in consensual sex with another man. No other significant differences were found between the accused condition and other groups on these two trait dimensions (prescriptive femininity: victim physical assault: $p=.288$; control: $p=.090$; proscriptive femininity: victim sexual assault: $p=.765$; victim physical assault: $p=.249$; control: $p=1.00$ ). Also, no significant differences were found between the accused man and other conditions on proscriptive masculinity (victim physical assault: $p=.291$; consensual sex: $p=.236$; control: $p=.202$ ). As in Study 1, it is once more interesting to note that the alleged perpetrator of sexual assault against a male victim was not regarded differently from the other conditions (excluding the victim of sexual assault) on proscriptive masculine traits, although he was clearly perceived as less prescriptively and proscriptively feminine than a man who had engaged in consensual homosexual sex.

Gender Differences Looking at the univariate effects for gender of the respondent, a significant effect was found on proscriptive feminine traits, $F(1,267)=19.08, p<.001$, $\eta_{\mathrm{p}}{ }^{2}=.07$, such that male respondents generally attributed more proscriptive feminine traits $(M=3.47, S D=.96)$ to target persons than female respondents $\operatorname{did}(M=2.99, S D=1.02$,
Cohen's $d=.48)$. Additionally, a significant effect was found on proscriptive masculine traits, $F(1,267)=5.22, p=.023$, $\eta_{\mathrm{p}}{ }^{2}=.02$, wherein male respondents generally attributed more proscriptive masculine traits $(M=3.84, S D=1.08)$ to the target person than female respondents did $(M=3.58, S D=1.06$, Cohen's $d=.24)$. Finally, a significant effect was found on explicit masculinity, $F(1,267)=3.96, p=.048, \eta_{\mathrm{p}}{ }^{2}=.02$, indicating that male respondents rated the target person as less masculine $(M=4.62, S D=1.22)$ than female respondents did $(M=4.94, S D=1.23$, Cohen's $d=.26)$. Hence, across conditions, male respondents generally viewed the male target somewhat more negatively than female respondents did.

\section{Manipulated Pictures}

The Chi-square test of homogeneity indicated that the proportion of selected feminized pictures was not equal across conditions, $\chi^{2}(4)=10.80, p=.029$. Respondents selected the feminized picture $50.9 \%(n=28)$ in the accused condition, $50.8 \%(n=30)$ in the victim of physical assault condition, $27.8 \%(n=15)$ in the control condition, $30.8 \%(n=16)$ in the victim of sexual assault condition, and $39.7 \%(n=23)$ in the consensual sex condition. However, separate follow-up $2 \times 2$ Chi-square tests with Yates Continuity Correction indicated there were no significant differences between the picture selection of the victim of sexual assault compared to the other conditions (consensual sex: $p=.440$; physical assault: $p=.051$; control: $p=.901$; accused: $p=.055$ ).

\section{General Discussion}

The three studies we presented in the present paper examined whether the theoretically familiar reference to rape as a gendering crime finds empirical support when testing observers' perceptions of male and female victims of sexual violence. 
Specifically, we tested whether victims of sexual assault were attributed more stereotypically feminine and less stereotypically masculine traits compared to a control or accused condition and whether they were expected to possess more feminine facial features. To disentangle the potential independent effects of perceived homosexuality and victimization, Study 3 additionally included conditions featuring a victim of physical assault and a male student who engaged in consensual sex with another man.

Partial support for our main hypothesis was found because both male and female victims of sexual assault were feminized on two of four character trait dimensions. Male and female victims were consistently attributed less proscriptive masculine traits than target persons in other conditions and more prescriptive feminine traits than target persons in the accused condition. The same pattern of feminization was not found in reaction to victims of physical assault, although respondents did rate a man who had engaged in consensual homosexual sex higher on proscriptive and prescriptive femininity compared to the accused male target. The specification of the other party's gender in the third study - contradicting the likely assumption that the male student was accused of sexually assaulting a woman - remarkably did not eliminate differences in feminization between the victim and accused condition, providing evidence that assumptions of homosexuality are not sufficient to explain feminization. This finding resonates with the suspicion that reactions of feminization are additionally intertwined with perceptions of (passive) victimhood. The results then lend some support to the hypothesis that sexual assault has a uniquely gendering effect (Quinn 2002), which cannot be ascribed to either interpersonal victimization or perceptions of homosexuality alone. On the other hand, no compelling evidence was found for theorizing that the perpetration of sexual violence simultaneously causes the (dominating) agent to be perceived as more masculine (Gilbert 2002; Mackinnon 1989).

It is notable that feminizing responses to the victim of sexual assault always occurred on the same two trait dimensions of proscriptive masculinity and prescriptive femininity, whereas no significant differences were found on the trait dimensions of prescriptive masculinity and proscriptive femininity. A plausible explanation for these findings is that feminization on the first two trait dimensions arguably entails a positive re-evaluation of the target person (e.g., assigning more warmth and less cynicism), whereas feminization on the latter trait dimensions entails a negative pattern of trait assignment (e.g., assigning more naivety and less competence to the target person). We speculate that respondents were unwilling to feminize a victim when they associated this with socially undesirable responses to victims. Alternatively, a possible methodological explanation for these findings is that the same character traits were employed across the three studies, risking the possibility that a different selection may have resulted in a different pattern of findings. Yet we find this explanation less plausible because we used a selection of traits not just representative of the BSRI (Bem 1974), but also of the competence-warmth (Fiske et al. 2002) and agencycommunion (Abele and Wojciszke 2007) dichotomies.

In the second study, we found some support for victim feminization, as well as support for character derogation of the accused. Though not all main effects were significant, the alleged female perpetrator was ascribed more proscriptive masculine and feminine traits, as well as less prescriptive masculine and feminine traits, than the victim and/or control condition. On the other hand, in the studies with a male target, the feminization effect of victimization was more prominent than the derogation of someone accused of perpetrating violence. Indeed, in the first study - where respondents in all likelihood assumed the male student was accused of assaulting a woman - no differences were found between the accused student and the control condition at all. A comparison between these studies indicates that gender norms are likely to interact with expectations of a perpetrator as they do with victim stereotypes.

Using a more indirect measure of feminization that tapped into observers' expectations of target persons' facial appearance, the results of Study 1 were in accordance with our hypothesis that respondents are more likely to select the feminized picture when the target person was described as a victim. Post-hoc comparisons of Studies 2 and 3, on the other hand, were not significant. Finally, in the second and third study we found that male respondents are likely to evaluate target persons more negatively than female respondents do.

\section{Theoretical Implications}

Although the present findings seem to support the feminization-normalization hypothesis as a way of making sense of male rape (Doherty and Anderson 2004; Graham 2006), it is important to consider how this account relates to, and potentially improves upon, other explanations. First, it is conceivable that the current reactions by observers can be encompassed under a broader reaction of "othering" the victim. Placing a victim outside the realm of our own (moral) world can be one strategy to reduce the threat the victim poses to our sense of justice or control (Cohen 2014; Lerner 1980). Hence, it is possible that feminizing the male victim of sexual assault, and feminizing the male student who willingly engaged in sexual relations with another man, were strategies that labeled the target person as gay, and hence as potential "Other"- violating heteronormativity (Javaid 2015b). However, this reasoning does not explain the results that were found in relation to the female victim, who was feminized on the same dimensions as the male victim. Instead, the present results seem to suggest that reactions follow stereotypes of victimhood and femininity, and they may thus be interpreted 
more specifically as an attempt of normalizing rather than othering. That is, by means of feminizing a (male or female) victim of sexual assault, the event is (re)interpreted in alignment with prescribed gender roles, normalizing the perceived victimization.

Kay et al. (2005) provide a second alternative explanation to the feminization hypothesis that suggests that respondents enhance victims on traits that are unrelated to their victimization, while derogating them on traits perceived as relevant to their victimization in order to justify the status quo. Our results are to a certain extent consistent with this view. We indeed found that the victim was enhanced in the eyes of the perceiver through the ascription of more positive feminine traits (e.g., warmth) and less negative masculine traits (e.g., arrogance). However, our results diverged from the victim enhancementderogation hypothesis in two ways. First, victims were only enhanced in the specific direction of the feminine stereotype. So, although an alternative explanation might be that victims are evaluated more positively as a consequence of their victimization, this positive evaluation only pertained to the feminine domain (e.g., victims were not judged as more competent than others). Second, the complementary victim enhancement-derogation hypothesis suggests that victims in the current study would be derogated on dimensions that observers can associate with the victimization (Kay et al. 2005). This can entail a decrease in the attribution of prescriptive masculine traits, such as competence, or an increase in proscriptive feminine traits, such as naivety. However, although victims were not enhanced on these dimensions, they were also not derogated. Although our results do not entirely comply with the victim enhancement-derogation hypothesis, the strategy of feminization/normalization does fit relatively well within the system justification framework (Jost and Kay 2005).

The feminization hypothesis is thus not incompatible with strategies of othering and system justification (or just world) motives, but seems a specifically apt framework through which to consider social reactions to victims of sexual violence. It suggests that observers may wield gender stereotypes in order to normalize their perceptions of sexual violence.

\section{Implicit Feminization}

Whereas the feminization of sexual assault victims in character traits was a consistent finding across our studies, results of the implicit feminization measure pose a greater interpretative challenge. Study 1 largely led to results in accordance with our hypothesis, where male victims were more frequently implicitly feminized compared to control target persons. Although our results followed a similar pattern in Study 2, the differences were not significant. The reason for this may be that respondents are already quite likely to pick the feminized picture of a woman, leaving less room to differentiate between experimental conditions. Differences between conditions were also not statistically significant in Study 3, but these results seemed to follow a different pattern from the first two studies because the selection frequencies of the feminized picture were higher in the physical assault victim and accused person condition. More research is necessary for accurate interpretation of the different findings between studies and to refine implicit measurements of observer reactions.

\section{Observer Effects}

Finally, results of Studies 2 and 3 indicated that male respondents generally evaluated the target person less positively than female respondents did. A fair number of studies have likewise indicated that men are generally less empathic toward victims than women, but not many of those studies included control conditions of non-victimized target persons (for an overview, see Grubb and Harrower 2008). In the current study, no significant multivariate effect for the interaction between experimental condition and gender of the respondent was found, indicating that some of the more unsympathetic reactions of male respondents toward victims may result from a less positive perception of others in general compared to female respondents (Felson and Palmore 2018). This is not to say that this bias is without indication of gender stereotyping because male respondents in the third study also rated male others as less masculine than female respondents did. Furthermore, Study 3 focused on a specific type of reaction, acknowledging the possibility that other types of (negative) reactions do interact with respondent gender. It is, for instance, conceivable that male respondents experience a greater distance between themselves and sexual assault victims and may hence feel less empathic toward them.

\section{Practice Implications}

In an age that is increasingly characterized by emphasis on victim inclusion, political correctness, and microaggressions (Campbell and Manning 2014), our findings provide insight into the more subtle ways in which third parties may react to a victim of sexual violence. Whereas Javaid (2015b, p. 275) concluded that "feminizing or gendering victimization is mostly seen within labels that are derogatory ..., pussies, sissies ... and so on," respondents in the current study feminized the victim in ways that resulted in the attribution of more positive traits and less negative traits. This is not to say that such feminization is harmless because even "benevolent" feminization may effectively work to police gender borders and create skewed power relations (Quinn 2002). It is presumably precisely in (sub)cultures where sexual violence against men is more prevalent that qualities deemed desirable in women are depreciated or even abhorred in men, making rape a particularly powerful tool of domination. To evaluate a man as 
warm in such a context may not be an act of benevolence at all, but indeed a (sugarcoated) devaluation of his character. Our results may facilitate the recognition of such feminizing reactions of third parties in daily life, although future research is needed to explore the relationships between (subtle/benevolent) feminization and more blatantly negative observer reactions such as victim blame and avoidance (Herbert and Dunkel-Schetter 1992).

The current findings do suggest that certain widespread misbeliefs about (male) sexual victimization cannot be confronted without also targeting gender stereotypes more broadly. Indeed, policymakers and anti-rape campaigners may wish to broaden the message that "real men can be raped" to include a deeper exploration and critique of our common expectations of what it means to be a "real man." This seems particularly important in light of the fact that concerns over "real" masculinity play a role in male victims" reluctance to seek support (Javaid 2016).

The present study finally highlights one of the complexities that can be experienced by male victims of sexual assault in particular (Mulkey 2004). Male victims who themselves struggle with an experienced loss of their identity may have an especially hard time regaining or reinventing a sense of their masculinity if their social surroundings are inclined to reactions of feminization (Clark 2014). Educators or counselors could use vignette studies with similar designs as described here to help confront others with their gendered expectations of victims.

\section{Limitations and Future Research}

The current study employed several fruitful ways to measure the feminizing effects of (sexual) victimization on observers' perceptions. However, the current design also suffers from several limitations. First, the narrative we provided to our respondents contained both specific and limited information. In all vignettes, we spoke of a "sexual assault" or "physical assault" with only a few hints at what may have happened (e.g., the offender undressed the victim or beat the victim). Particularly in the case of a sexual assault of a woman versus the sexual assault of a man, interpretations of the respondents may have varied greatly. Indeed, answers to open questions show that whereas respondents usually expect penetrative sex in the case of a female victim, they more frequently mentioned "inappropriate touching" and similar misbehaviors when the victim was a man. A future vignette could strongly emphasize that someone was either uncontestably a rape victim or a perpetrator. There is also much research to be done concerning the specific circumstances in which observers are inclined to react in one way, such as by feminizing, versus another in response to a victim. We are currently complementing quantitative data with qualitative data to shed more light on how respondents employ stereotypes to fill in the gaps of different victimization stories.

Second, the use of morphed pictures in social psychological experimental designs, such as those we employed in our series of studies, requires further testing and development. This instrument is increasingly popular in (evolutionary) studies regarding mate preferences (e.g., Jones et al. 2018) and, more exceptionally, sexuality and sexism (e.g., Zheng and Zheng 2015). However, it is most frequently used to measure a preference of the respondent rather than as an indicator of the perception or evaluation of a target person. More pilot testing is needed with different faces to get a firmer grip of the extent to which gendered facial manipulation in itself influences perceptions (Sutherland et al. 2015). Additionally, it remains important to investigate the relations between this implicit measure and explicit observer evaluations of victims.

In future research it would finally be interesting to use vignettes in which both the victim and the perpetrator play a role, after which respondents make judgments about both parties. This taps into the relational aspect of victimization, where the moral transgression establishes both a moral agent and a moral patient (Gray and Wegner 2009). It may also give a clearer indication of the suggestion that sexual violence serves to simultaneously feminize or emasculate the victim and masculinize the perpetrator (Gilbert 2002).

\section{Conclusion}

According to Quinn (2002, p. 399), forms of sexual violence can be "mechanisms through which gendered boundaries are patrolled and evoked and by which deeply held identities are established" (emphasis added). The current findings lend empirical support to the notion that sexual violence has the potential to create feminized perceptions of victims, and they affirm the accuracy of the description of sexual violence/rape as a "gendering crime." Whereas in gender studies scholars mostly refer to feminization as a mode or function of rape, from a social psychological perspective, we may best understand feminization as one potential effect of rape that results from (automatic) coping efforts to normalize a threat (Cohen 2014). Hence, we suggest that a comprehensive understanding of social reactions to rape victims requires acknowledging their intertwinement with gender stereotypes.

Acknowledgments This work was supported by the Nederlandse Organisatie voor Wetenschappelijk Onderzoek [grant number 406-15157] and Fonds Slachtofferhulp [number 17.01.03]. We would like to thank Job Vossen for his conceptual input and feedback on previous versions of this manuscript.

Funding This study was funded by the Netherlands Organisation for Scientific Research [grant number 406-15-157] and by Fonds Slachtofferhulp [number 17.01.03]. 


\section{Compliance with Ethical Standards}

Informed Consent All respondents gave informed consent.

Conflict of Interest The authors declare that they have no further conflict of interest.

Open Access This article is distributed under the terms of the Creative Commons Attribution 4.0 International License (http:// creativecommons.org/licenses/by/4.0/), which permits unrestricted use, distribution, and reproduction in any medium, provided you give appropriate credit to the original author(s) and the source, provide a link to the Creative Commons license, and indicate if changes were made.

\section{References}

Abele, A. E. (2003). The dynamics of masculine-agentic and femininecommunal traits: Findings from a prospective study. Journal of Personality and Social Psychology, 85(4), 768-776. https://doi. org/10.1037/0022-3514.85.4.768.

Abele, A. E., \& Wojciszke, B. (2007). Agency and communion from the perspective of self versus others. Journal of Personality and Social Psychology, 93(5), 751-763. https://doi.org/10.1037/0022-3514.93. 5.751.

Abele, A. E., \& Wojciszke, B. (2014). Communal and agentic content in social cognition: A dual perspective model. Advances in Experimental Social Psychology, 50, 195-255. https://doi.org/10. 1016/B978-0-12-800284-1.00004-7.

Ainsworth, C. (2015). Sex redefined. Nature, 518(7539), 288-291. https://doi.org/10.1038/518288a.

Bem, S. L. (1974). The measurement of psychological androgyny. Journal of Consulting and Clinical Psychology, 42(2), 155-162. https://doi.org/10.1037/h0036215.

Bergoffen, D. (2009). Exploiting the dignity of the vulnerable body: Rape as a weapon of war. Philosophical Papers, 38(3), 307-325. https:// doi.org/10.1080/05568640903420889.

Bonthuys, E. (2008). Putting gender into the definition of rape or taking it out? Feminist Legal Studies, 16(2), 249-260. https://doi.org/10. 1007/s10691-008-9091-4.

Bosma, A. K., Mulder, E., Pemberton, A., \& Vingerhoets, A. J. (2018). Observer reactions to emotional victims of serious crimes: Stereotypes and expectancy violations. Psychology, Crime \& Law, 24(9), 957-977. https://doi.org/10.1080/1068316X.2018.1467910.

Breiding, M. J. (2014). Prevalence and characteristics of sexual violence, stalking, and intimate partner violence victimization-National Intimate Partner and sexual violence survey, United States, 2011. Morbidity and Mortality Weekly Report Surveillance Summaries, 63(8), 1-18 https://www.cdc.gov/mmwr/preview/mmwrhtml/ ss6308a1.htm.

Brown, G. (2017). Project Unbreakable [blog post]. Retrieved from http://projectunbreakable.tumblr.com/ . Accessed 25 Aug 2018.

Butler, J. (1988). Performative acts and gender constitution: An essay in phenomenology and feminist theory. Theatre Journal, 40(4), 519531. https://doi.org/10.2307/3207893.

Butler, J. (1994). Against proper objects. Differences: A Journal of Feminist Cultural Studies, 6(2-3), 1-27 http://www.sfu.ca/ $\sim$ decaste/OISE/page2/files/ButlerAgainstProper.pdf.

Cahill, A. J. (2000). Foucault, rape, and the construction of the feminine body. Hypatia, 15(1), 43-63. https://doi.org/10.1111/j.1527-2001. 2000.tb01079.x.
Campbell, B., \& Manning, J. (2014). Microaggression and moral cultures. Comparative Sociology, 13(6), 692-726. https://doi.org/10. 1163/15691330-12341332.

Clark, J. N. (2014). A crime of identity: Rape and its neglected victims. Journal of Human Rights, 13, 146-169. https://doi.org/10.1080/ 14754835.2014.886952.

Code, L. (2009). A new epistemology of rape? Philosophical Papers, 38(3), 327-345. https://doi.org/10.1080/05568640903420897.

Cohen, C. (2014). Male rape is a feminist issue: Feminism, governmentality and male rape. Hampshire: Palgrave Macmillan.

Connell, R. W., \& Messerschmidt, J. W. (2005). Hegemonic masculinity: Rethinking the concept. Gender \& Society, 19(6), 829-859. https:// doi.org/10.1177/0891243205278639.

Cuddy, A. J., Wolf, E. B., Glick, P., Crotty, S., Chong, J., \& Norton, M. I. (2015). Men as cultural ideals: Cultural values moderate gender stereotype content. Journal of Personality and Social Psychology, 109(4), 622-635. https://doi.org/10.1037/pspi0000027.

DeBruine, L., \& Jones, B. (2017). Young adult white faces with manipulated versions (Version 1). figshare. https://doi.org/10.6084/m9. figshare.4220517.v1

Doherty, K., \& Anderson, I. (2004). Making sense of male rape: Constructions of gender, sexuality and experience of rape victims. Journal of Community \& Applied Social Psychology, 14(2), 85-103. https://doi.org/10.1002/casp.765.

Donnelly, K., \& Twenge, J. M. (2017). Masculine and feminine traits on the Bem sex-role inventory, 1993-2012: A cross-temporal metaanalysis. Sex Roles, 76(9-10), 556-565. https://doi.org/10.1007/ s11199-016-0625-y.

Dunnett, C. W. (1985). Multiple comparisons between several treatments and a specified treatment. In T. Caliński \& W. Klonecki (Eds.), Linear statistical inference (pp. 33-47). New York: Springer.

Eagly, A. H., \& Steffen, V. J. (1984). Gender stereotypes stem from the distribution of women and men into social roles. Journal of Personality and Social Psychology, 46(4), 735-754. https://doi. org/10.1037/0022-3514.46.4.735.

Faul, F., Erdfelder, E., Lang, A.-G., \& Buchner, A. (2007). G*power 3: A flexible statistical power analysis program for the social, behavioral, and biomedical sciences. Behavior Research Methods, 39(2), 175191. https://doi.org/10.3758/BF03193146.

Felson, R. B., \& Palmore, C. (2018). Biases in blaming victims of rape and other crime. Psychology of Violence, 8(3), 390-399. https://doi. org/10.1037/vio0000168.

Fiske, S. T., Cuddy, A. J. C., Glick, P., \& Xu, J. (2002). A model of (often mixed) stereotype content: Competence and warmth respectively follow from perceived status and competition. Journal of Personality and Social Psychology, 82(6), 878-902. https://doi. org/10.1037//0022-3514.82.6.878.

Gavey, N. (2005). Just sex? The cultural scaffolding of rape. London: Routledge.

Gear, S., \& Ngubeni, K. (2002). Daai ding: Sex, sexual violence and coercion in men's prisons [online]. Johannesburg: CSVR https:// www.csvr.org.za/publications/1348-daai-ding-sex-sexual-violenceand-coercion-in-mens-prisons.

Gilbert, P. R. (2002). Discourses of female violence and societal gender stereotypes. Violence Against Women, 8(11), 1271-1300. https://doi. org/10.1177/107780102237405.

Graham, R. (2006). Male rape and the careful construction of the male victim. Social \& Legal Studies, 15(2), 187-208. https://doi.org/10. $1177 / 0964663906063571$.

Gray, K., \& Wegner, D. M. (2009). Moral typecasting: Divergent perceptions of moral agents and moral patients. Journal of Personality and Social Psychology, 96(3), 505-520. https://doi.org/10.1037/ a0013748.

Grubb, A., \& Harrower, J. (2008). Attribution of blame in cases of rape: An analysis of participant gender, type of rape and perceived 
similarity to the victim. Aggression and Violent Behavior, 13, 396405. https://doi.org/10.1016/j.avb.2008.06.006.

Hafer, C. L. (2000). Do innocent victims threaten the belief in a just world? Evidence from a modified Stroop task. Journal of Personality and Social Psychology, 79(2), 165-173. https://doi. org/10.1037/0022-3514.79.2.165.

Helgeson, V. S. (1994). Prototypes and dimensions of masculinity and femininity. Sex Roles, 31(11-12), 653-682. https://doi.org/10.1007/ BF01544286

Herbert, T. B., \& Dunkel-Schetter, C. (1992). Negative social reactions to victims: An overview of responses and their determinants. In L. Montada, S.-H. Filipp, \& M. J. Lerner (Eds.), Life crises and experiences of loss in adulthood (pp. 497-518). Hillsdale: Lawrence Erlbaum Associates, Inc..

Howard, J. A. (1984a). The" normal" victim: The effects of gender stereotypes on reactions to victims. Social Psychology Quarterly, 47(3), 270-281. https://doi.org/10.2307/3033824.

Howard, J. A. (1984b). Societal influences on attribution: Blaming some victims more than others. Journal of Personality and Social Psychology, 47(3), 494-505. https://doi.org/10.1037/0022-3514. 47.3.494.

Javaid, A. (2015a). Male rape myths: Understanding and explaining social attitudes surrounding male rape. Masculinities and Social Change, 4(3), 270-294. https://doi.org/10.17583/MCS.2015.1579.

Javaid, A. (2015b). The dark side of men: The nature of masculinity and its uneasy relationship with male rape. Journal of Men's Studies, 23(3), 271-292. https://doi.org/10.1177/1060826515600656.

Javaid, A. (2016). Male rape, stereotypes, and unmet needs: Hindering recovery, perpetuating silence. Violence and Gender, 3(1), 7-13. https://doi.org/10.1089/vio.2015.0039.

Jones, B. C., Hahn, A. C., Fisher, C. I., Wang, H., Kandrik, M., Han, C., ... O'Shea, K. J. (2018). No compelling evidence that preferences for facial masculinity track changes in women's hormonal status. Psychological Science, 29(6), 996-1005. https://doi.org/10.1177/ 0956797618760197

Jost, J. T., \& Banaji, M. R. (1994). The role of stereotyping in systemjustification and the production of false consciousness. British Journal of Social Psychology, 33(1), 1-27. https://doi.org/10.1111/ j.2044-8309.1994.tb01008.x.

Jost, J. T., \& Kay, A. C. (2005). Exposure to benevolent sexism and complementary gender stereotypes: Consequences for specific and diffuse forms of system justification. Journal of Personality and Social Psychology, 88(3), 498-509. https://doi.org/10.1037/00223514.88.3.498.

Kay, A. C., Jost, J. T., \& Young, S. (2005). Victim derogation and victim enhancement as alternate routes to system justification. Psychological Science, 16(3), 240-246. https://doi.org/10.1111/j. 0956-7976.2005.00810.x.

Koenig, A. M., \& Eagly, A. H. (2014). Evidence for the social role theory of stereotype content: Observations of groups' roles shape stereotypes. Attitudes and Social Cognition, 107(3), 371-392. https://doi. org/10.1037/0037215.

Lamb, S. (Ed.). (1999). New versions of victims: Feminists struggle with the concept. New York: NYU Press.

Lerner, M. J. (1980). The belief in a just world: A fundamental delusion. New York: Plenum Press.

Little, B., \& Terrance, C. (2010). Perceptions of domestic violence in lesbian relationships: Stereotypes and gender role expectations. Journal of Homosexuality, 57, 429-440. https://doi.org/10.1080/ 00918360903543170.

MacKinnon, C. A. (1989). Toward a feminist theory of the state. Cambridge: Harvard University Press

Marcus, S. (1992). Fighting bodies, fighting words: A theory and politics of rape prevention. In J. Butler \& J. Scott (Eds.), Feminists theorize the political (pp. 385-403). New York: Routledge.
Mardorossian, C. M. (2014). Framing the rape victim: Gender and agency reconsidered. New Brunswick: Rutgers University Press.

Masser, B., Lee, K., \& McKimmie, B. M. (2010). Bad woman, bad victim? Disentangling the effects of victim stereotypicality, gender stereotypicality and benevolent sexism on acquaintance rape victim blame. Sex Roles, 62(7-8), 494-504. https://doi.org/10.1007/ s11199-009-9648-y.

Mulkey, M. (2004). Recreating masculinity: Drama therapy with male survivors of sexual assault. The Arts in Psychotherapy, 1(31), 1928. https://doi.org/10.1016/j.aip.2003.11.003.

Papendick, M., \& Bohner, G. (2017). Passive victim - Strong survivor? Perceived meaning of labels applied to women who were raped. PLoS One, 12(5), e0177550. https://doi.org/10.1371/journal.pone.0177550.

Pilcherm, J., \& Whelehan, I. (2004). 50 key concepts in gender studies. London: Sage Publications.

Prentice, D. A., \& Carranza, E. (2002). What women and men should be, shouldn't be, are allowed to be, and don't have to be: The contents of prescriptive gender stereotypes. Psychology of Women Quarterly, 26(4), 269-281. https://doi.org/10.1111/1471-6402.t01-1-00066.

Proulx, T., Inzlicht, M., \& Harmon-Jones, E. (2012). Understanding all inconsistency compensation as a palliative response to violated expectations. Trends in Cognitive Sciences, 16(5), 285-291. https:// doi.org/10.1016/j.tics.2012.04.002.

Quinn, B. A. (2002). Sexual harassment and masculinity: The power and meaning of 'girl watching'. Gender and Society, 16, 386-402. https://doi.org/10.1177/0891243202016003007.

Ridgeway, C. L. (2009). Framed before we know it: How gender shapes social relations. Gender \& Society, 23(2), 145-160. https://doi.org/ 10.1177/0891243208330313.

Sivakumaran, S. (2005). Male/male rape and the taint of homosexuality. Human Rights Quarterly, 27, 1274-1306. https://doi.org/10.1353/ hrq.2005.0053.

Skjelsbaek, I. (2001). Sexual violence and war: Mapping out a complex relationship. European Journal of International Relations, 7(2), 211-237. https://doi.org/10.1177/1354066101007002003.

Spence, J. T., \& Helmreich, R. L. (1978). Masculinity and femininity: Their psychological dimensions, correlates, and antecedents. Austin: University of Texas Press.

Stemple, L., \& Meyer, I. H. (2014). The sexual victimization of men in America: New data challenge old assumptions. American Journal of Public Health, 104(6), e19-e26. https://doi.org/10.2105/AJPH. 2014.301946.

SurvivorsUK. (2018). Male rape and sexual abuse. In the media. Retrieved from https:/www.survivorsuk.org/about-us/pressmedia/in-the-media/. Accessed 18 Aug 2018.

Sutherland, C. A., Young, A. W., Mootz, C. A., \& Oldmeadow, J. A. (2015). Face gender and stereotypicality influence facial trait evaluation: Counter-stereotypical female faces are negatively evaluated. British Journal of Psychology, 106(2), 186-208. https://doi.org/10. 1111/bjop.12085.

Wasarhaley, N. E., Lynch, K. R., Golding, J. M., \& Renzetti, C. M. (2017). The impact of gender stereotypes on legal perceptions of lesbian intimate partner violence. Journal of Interpersonal Violence, 32(5), 635-658. https://doi.org/10.1177/ 0886260515586370 .

Wood, W., \& Eagly, A. H. (2015). Two traditions of research on gender identity. Sex Roles, 73(11-12), 461-473. https://doi.org/10.1007/ s11199-015-0480-2.

Zheng, L., \& Zheng, Y. (2015). Young gay men's sexism predict their male facial masculinity preference in China. Personality and Individual Differences, 76, 183-186. https://doi.org/10.1016/j.paid. 2014.12.022.

Publisher's Note Springer Nature remains neutral with regard to jurisdictional claims in published maps and institutional affiliations. 